\title{
Accessibility Issues for Poll Sites and Voters
}

\author{
Bruce Adelson
}

\begin{abstract}
Polling locations that are accessible to all voters is a cornerstone of elections being free and fair for all voters. Although we often think of accessibility as it relates to voters who have physical disabilities, accessibility can also be related to the comfort that voters feel when entering the place that has been designated for in-person voting. This case discusses these definitions of accessibility and others that have been addressed by legislative action and decisions made by courts in the United States.
\end{abstract}

Keywords Voting • Accessible $\bullet$ Equal $\bullet$ Convenient $\bullet$ Comfortable

Voting accessibility is essentially about making voting easier, open, and available. Voting accessibility is often used as a term of art to mean accessibility to people with disabilities, without the presence of physical impediments to voting. Such impediments can be ballots without accessible alternatives for blind people and polling place doorways too narrow for wheelchairs.

B. Adelson $(\bowtie)$

Federal Compliance Consulting, LLC, Potomac, MD, USA

e-mail: badelson1@comcast.net

(C) The Author(s) 2019

M. Brown et al. (eds.), The Future of Election Administration, Elections, Voting, Technology, https://doi.org/10.1007/978-3-030-18541-1_6 
Voting accommodations for people with disabilities essentially provide equal, level playing field access to voting so as not to infringe on "fundamental voting rights" and cause "irreparable injury" to voters. ${ }^{1}$ For voters with disabilities, accessibility to voting and voting accommodations include talking voting machines for blind voters, as a federal court decided on the eve of the 2016 presidential election. Failure to provide such machines "and all other accessible voting technology available for persons with disabilities" violates federal guarantees against disability discrimination. ${ }^{2}$

Accessibility, though, encompasses more than disability accommodations. Accessibility means openness, availability, the quality of being able to be reached or entered or easy to use. In this definitional context, accessibility is impacted and influenced by considerations of race, language, and culture. More than questions of legality and voting requirements, such as those of the Voting Rights Act of $1965,{ }^{3}$ accessibility in voting also includes the very subjective notion of a voter not being discomfited when entering a polling place.

This subjectivity of comfort played out in real time in 2004, when a rural Southern county attempted to move a polling place to a building that had been a Ku Klux Klan (KKK) headquarters as recently as the 1970s. Although the county reportedly did not realize the history of its proposed new voting location, the same county immediately realized the problematic effect such a polling place shift would have on AfricanAmerican voters, especially those old enough to have lived through this county's KKK and Jim Crow eras. These voters were so upset and adversely influenced by having to choose whether to vote in this problematic building or not vote at all that many planned to stay home on Election Day. This ostensible polling location was thus not "accessible" in the term's definitional sense to those voters, which is evident from the county's reversal of its decision to move the polling with the encouragement of the US Department of Justice.

${ }^{1}$ League of Women Voters of North Carolina v. North Carolina, 769 F.3d 224, 247 (4th Cir., 2014).

${ }^{2}$ Gray et al., p. St. Louis City Board of Election Commissioners, Case No. 4:16-cv-01548, (W.D., Mo., 2016). The author was the Americans with Disabilities Act consulting expert for plaintiffs in this case.

${ }^{3} 42$ U.S.C. $\S \S 1973$ to 1973 aa-6. 
Anecdotal examples abound of such accessibility affecting and influencing decisions whether or not to exercise the fundamental right to vote. The following anecdotes are among the most telling.

The San Carlos Apache Nation is located in southeastern Arizona and encompasses three Arizona counties-Gila, Graham, and Pinal, with the Pinal County portion virtually uninhabited.

In 2002, the U.S. Census Bureau determined ${ }^{4}$ through population analysis that Gila and Graham Counties must provide election information in the Apache language under Section 203 of the Voting Rights Act. ${ }^{5}$ Election information as defined by Section 203 includes: "any registration or voting notices, forms, instructions, assistance, or other materials or information relating to the electoral process, including ballots.... [The 203 requirements] should be broadly construed to apply to all stages of the electoral process, from voter registration through activities related to conducting elections, including, for example the issuance, at any time during the year, of notifications, announcements, or other informational materials concerning the opportunity to register, the deadline for voter registration, the time, places and subject matters of elections, and the absentee voting process."

For Native American and Alaska Native languages that are historically unwritten, as is Apache, only oral assistance concerning election information and material is required. ${ }^{7}$

"Under Section 203, which applies nationwide, a variety of triggering formulas assess minority group size and high rates of illiteracy (measured by educational completion below the fifth grade) to determine languageassistance coverage. As originally enacted and as amended in 1982, Section 203 mandates language assistance in a state or political subdivision in which more than $5 \%$ of the voting-age citizens are members of a languageminority group and are limited-English-proficient, and where the illiteracy rate for that group exceeds the national illiteracy rate. To address the problem of excluding coverage for large numbers of language-minority voters who might not meet the $5 \%$ test in many of the country's largest

\footnotetext{
${ }^{4}$ Section 203 determinations for 2016 - Federal Register / Vol. 81, No. 233 / Monday, December 5, 2016.

${ }^{5} 42$ U.S.C. § 1973aa-1a.

${ }^{6} 28$ Code of Federal Regulations PART 55 et seq., Implementation of the Provisions of the Voting Rights Act Regarding Language Minority Groups.

${ }^{7}$ Id.
} 
population centers, Congress amended Section 203 in 1992 to impose an additional test focusing on absolute numbers: a jurisdiction with a language-minority group constituting a population with over 10,000 voting-age limited-English-proficient citizens and possessing an illiteracy rate above the national average is also covered." 8

In 2002, when Gila and Graham Counties faced new Apache language Section 203 obligations, voting and election participation among the San Carlos Apaches was low. Neither county provided Apache language assistance for voting and elections prior to the 2002 Census Bureau determination. The Department of Justice (DOJ), which enforces Section 203, launched a nationwide education and enforcement program concerning the 2002 Section 203 language requirements. Gila and Graham counties were among the counties selected by DOJ for inclusion in this program. ${ }^{9}$

DOJ worked with both counties and recommended various innovations to foster Section 203 Apache language compliance. These included hiring new county election workers who spoke Apache; hiring new county poll workers who could provide Apache language assistance at the polls; implementing joint voter registration efforts by both counties, led by election workers who spoke Apache; and launching a joint county publicity program informing the San Carlos Apache Nation of the counties' new Apache Language Election Information Programs.

Gila and Graham counties publicized and held a joint Voter Registration Day in Bylas, the San Carlos capital, in the Bylas community center. The particular Voter Registration Day was selected to coincide with a wellknown community event-a free farm animal veterinary clinic.

Inside the center, both counties set up their voter registration materials in two small rooms adjacent to a large open space filled with veterinarians, nurses, operating tables, and large, noisy farm animals. The clinic and voter registration event ran all day, with both featuring steady streams of human customers. Many San Carlos Apaches registered to vote for the first time in their lives, with new voters speaking approvingly of the counties' new Apache language efforts.

The most compelling scene played out on the main road facing the center's front door. Walking to the clinic to register to vote for the first

${ }^{8}$ Language Accommodation and The Voting Rights Act: Angelo N. Ancheta; Santa Clara University School of Law.

${ }^{9}$ The author was the DOJ attorney responsible for Gila and Graham Counties' Section 203 compliance. 
time ever were five women, tribal elders, in traditional San Carlos Apache dress. They had lived on the reservation all of their lives. They lived through the 1948 Arizona Supreme Court decision that struck down previous court rulings that infringed upon Native Americans' right to vote. ${ }^{10}$ As the 1948 Court decided, "In a democracy, suffrage is the most basic civil right, since its exercise is the chief means whereby other rights may be safe-guarded. To deny the right to vote where one is legally entitled to do so, is to do violence to the principles of freedom and equality."

These five tribal elders, who spoke Apache and could speak and read little English, had never felt comfortable registering to vote, in large part because of the language barrier. Now, with Gila and Graham Counties providing voting and election information and assistance in their native language, the women finally felt comfortable enough to register to vote. Voting had become "accessible" to them. They and other San Carlos Apaches became first-time voters that day, signing up amidst the tumult of multiple large animal surgeries in the summer of 2002.

The Apache Language Election Information Program had its desired effect that year and subsequently the number of Apaches who registered to vote and voted in Gila and Graham County elections increased. The nascent Apache language election program substantially contributed to the newly accessible election process on this Indian reservation astride these two rural Arizona counties.

In the early 2000s, a small town in the Deep South (population under 2000 people) held elections for aldermen to represent residents on the town council. The town elected aldermen from four districts. One district was majority African American. For purposes of this chapter, we will refer to this district as District 4.

This district had not elected an African American to serve on the town council since the nineteenth century. Through Jim Crow, racial violence, discrimination, and impediments to voting, black people living in this town grew less and less interested in exercising their franchise.

As voting restrictions eased and voting rights for all citizens became part of federal law, African-American voters in District 4 continued to register to vote and turnout at election time in low numbers, much lower than comparative rates for white residents.

Black District 4 voters revealed one reason for their voting disinterest. The District 4 poll workers had largely remained the same for decades,

${ }^{10}$ Harrison v. Laveen, 196 P.2d 456 (Ariz. 1948). 
going back to the 1960s when towns and cities in this state routinely devised invidious methods for discouraging and preventing AfricanAmerican residents from exercising their voting rights. Black people commented about how they encountered Jim Crow reminders every Election Day, when the same group of 1960s era white poll workers staffed the District 4 polling place. Instead of having to relive past racial injustice, they decided to just stay home and not vote.

This changed for one early 2000s Election Day when a new white election commissioner took office on the town's election board. The new commissioner told the author he wanted to increase African-American voter participation, especially in District 4 . A town resident all of his life, he had long wondered why black voters turned out to vote at such low rates, especially with the town's overall African-American town population exceeding 30 percent.

He asked the author for ways to increase African-American District 4 turnout. Recommendations and ideas were shared. Finally, the suggestion was made to hire more African-American poll workers to create a different, more welcoming, and more "accessible" election experience. The commissioner embraced the idea, although he noted that many longtime poll workers may not react well to sharing Election Day responsibilities or being replaced by new election workers. The commissioner also recognized that some other town residents may not take kindly to his plan. However, he wanted to try, with some anxieties perhaps assuaged by support from the Justice Department.

The local election board implemented this small change so that on Election Day, there were new faces manning the voter registration tables at the District 4 polling place. African-American voter turnout increased dramatically that day, perhaps to record levels of participation. After the votes were tallied and the results certified, District 4 voters had elected an African-American alderman for the first time in over 100 years.

As discussed, accessible voting most often refers to voting accessibility for people with disabilities. However, accessibility should be viewed as more all-encompassing and far-reaching. Indeed, the following description of accessible voting from the United Kingdom's Electoral Commission well captures this all-encompassing breadth:

Accessible Voting for All --- Anyone who's eligible to vote on polling day should be able to do so in a confident manner. Polling station staff [sic] are trained to provide assistance to any voter who asks for it. 
The key terms of accessible to all, and being able to vote in a "confident manner" speak volumes about voting being equally open, available, convenient, and comfortable. The anecdotes recounted in this chapter are not unique. Similar experiences occur in communities across the United States with unfortunate regularity. Perhaps when "accessible" voting is embraced in its full definitional meaning, the occurrences of inaccessible voting will recede and disappear into history.

Open Access This chapter is licensed under the terms of the Creative Commons Attribution 4.0 International License (http://creativecommons.org/licenses/ by $/ 4.0 /)$, which permits use, sharing, adaptation, distribution and reproduction in any medium or format, as long as you give appropriate credit to the original author(s) and the source, provide a link to the Creative Commons licence and indicate if changes were made.

The images or other third party material in this chapter are included in the chapter's Creative Commons licence, unless indicated otherwise in a credit line to the material. If material is not included in the chapter's Creative Commons licence and your intended use is not permitted by statutory regulation or exceeds the permitted use, you will need to obtain permission directly from the copyright holder.

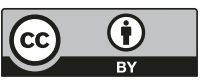

